\title{
Utilization of Some Artichoke Processing Wastes In Elongation of Cold Storage of Meat Patties
}

\author{
Mona,H.Bekhet ${ }^{1}$, Magda,S.Sharara ${ }^{2}$
}

\begin{abstract}
The edible part of artichoke head is receptacle, meanwhile other parts represent wastes are removed during the processing of artichoke although they contain a considerable amount of phenolic compounds and antioxidant activity, so the present study aimed to utilize of these wastes in preservation of meat patties during cold storage compared to some artificial preservatives such $\mathrm{So}_{2}$ and sodium ascorbate .Six samples of meat patties with deferent levels of artichoke wastes extract and/or $\mathrm{So}_{2}$ and sodium ascorbate were prepared. Colour, $\mathrm{pH}$ value, oxidative stability and bacterial load were estimated for all samples during the cold storage period ( $0,3,6,9$ days). Data showed that, red colour of meat patties samples decreased significantly, meanwhile blue colour increased significantly and slightly changes occurred in yellow colour in all samples during storage. Samples which contained artichoke wastes extract showed a slight changes in $\mathrm{pH}$ value compared with other treatments during storage . Addition of artichoke wastes to meat patties reduced the total count of bacteria compared to control sample and those with $\mathrm{So}_{2}$ and sodium ascorbate, meanwhile samples treated with artichoke wastes extracts had no coliform group till the end of storage period. Artichoke wastes extract could retard oxidation and kept each of peroxide value and thiobarbituric acid low during storage compared with control one or those contained artificial preservatives. All samples of different treatments were accepted by panelists in all organolyptic properties within storage period except control treatment and treatment with $\mathrm{So}_{2}$.
\end{abstract}

Keywords: Artichoke, artichoke wastes, meat patties, antioxidants, phenolic content, natural antioxidant.

\section{INTRODUCTION}

Consumers increasingly demand healthier meat products, if possible free of chemical additives. The use of natural preservatives to increase the shelf life of meat products is a promising technology since many vegetable substances have antioxidant and antimicrobial properties (Banon et al., 2007). Phenolic compounds are commonly found in both edible and nonedible plants, and they have been reported to have multiple biological effects, including antioxidant activity (Loliger, 1991). Crude extract of fruits, herbs, vegetables, cereals, and other plant materials rich in phenolic compounds are increasingly of interest in the food industry because they retard oxidative degradation of lipids and thereby improve the quality and nutritional value of food (Loliger, 1991). The importance of the antioxidant constituents of plant materials in the maintenance of health and protection from coronary heart disease and cancer is also raising interest among scientists, food manufacturers and consumers as the trend of the future is moving towards functional food with specific health effects (Loliger, 1991). Artichoke is of special interest due to its high content of phenolic compounds, globe artichoke (Cynara scolymus L.) ,belonging to the family of Asteraceae (Compositae), is an herbaceous perennial crop, widely cultivated in the Mediterranean area, (Bianco, 2005). The heads, i.e., the large immature inflorescences with edible fleshly leaves (bracts) and receptacle, are used worldwide and represent a fundamental ingredient of the Mediterranean diet. The phenolics in artichoke include cynarin (1,3-diO-caffeoylquinic acid), luteolin, cynaroside (luteolin-7O- glucoside), scolymoside (luteolin-7-rutinoside); phenolic acids such as caffeic, coumaric, hydroxycinnamic, ferulic, caffeoylquinic acid derivatives; mono- and dicaffeoylquinic acids, including chlorogenic; acid alcohols; flavonoid glycosides, among others, ( Fratianni et al., 2007). The present of phytochemical in artichoke has been well documented, the leaves being higher in medical value than flowers, with antihepatoxic, choleretic, diuretic, hypocholesterolemic and antilipidemic properties that are attributed to the phenolic composition (Mulinacci et al., 2004). The residues proceeding from artichoke industry can form up to $60 \%$ of the harvested plant materials, the final management of these wastes representing an additional problem. Until the present, the common disposal of artichoke raw material is as organic mass, animal feed, and fuel and fiber production. Nonetheless, owing to the antioxidants capacity of polyphenols and their possible implication in human health in prevention of cancer, cardiovascular diseases and other pathologies. Artichoke raw material being subjected to new chemical analysis to determine its phenolic composition (Rabaneda et al., 2003). The chemical composition of artichoke leaves have been

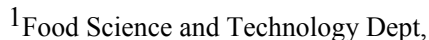

${ }^{2}$ Food Science and Technology Dept.,

Fac.of Agric., Alexandria. Univ.,

21545, El- Shatby, Alexandria- Egypt

Received March 15, 2012, Accepted March29, 2012
} 
studied extensively and have been found to be a rich source of polyphenolic compounds, with mono- and dicaffeoylquinic acids and flavonoids as the major chemical components (Dranik et al., 1996).

The present study aimed to utilize of antioxidant and antimicrobial chemical substances of industrial processing artichoke wastes in increasing the shelf life of meat patties by using of artichoke waste extract in different concentration comparing with sulpher dioxide and sodium ascorbate as a common preservatives in meat processing.

\section{MATERIALS AND METHODS}

\section{Materials:-}

Artichoke processing wastes including outer and inner bracts, pedicle of artichoke head and part of receptacle, whose remain after artichoke processing were used in this study. Artichoke processing wastes were obtained from Sonac company for preservative food and brought to pilot plant of Food Science and Technology Department, Faculty of Agriculture, Alex. University. The samples were minced 3 times through a meat mincer then dried at $40 \pm 5{ }^{\circ} \mathrm{C}$ in an air oven until drying (24 hrs), ground to pass through 60 mesh sieve, packed in polyethylene bags and kept at room temperature until used.

Boneless lean beef meat and beef tallow, common salt, and polyethylene bags were brought from the local market at Alexandria city, Egypt.

Analytical chemicals:-The chemicals used in this study were obtained from Food Science and Technology Department. Faculty of Agriculture, Alex. University, Egypt.

\section{Methods:-}

\section{Technological methods:-}

Meat patties preparation: The boneless lean beef meat was minced after mixing with beef tallow at ratio of 9:1 $\mathrm{w} / \mathrm{w}$ by passing three times through a $5 \mathrm{~mm}$ plate of meat mincer, then $2 \%$ common fine salt, was added to minced meat .

Six treatments of meat patties with different levels of preservatives (mg per $\mathrm{Kg}$ of meat) were prepared as follows: -

A (control without preservatives), B (meat +100 $\mathrm{So}_{2}$ as sodium metabisulfate), $\mathrm{C}$ (meat $+100 \mathrm{So}_{2}+400$ sodium ascorbate), $\mathrm{D}$ (meat $+100 \mathrm{So}_{2}+200$ artichoke waste extract), E ( meat +400 artichoke waste extract) and $\mathrm{F}$ (meat +800 artichoke waste extract).

Patties were formed using a burger machine $(100 \mathrm{~g}$ / patty), to give average dimensions of $10 \mathrm{~cm}$ diameter and $1.5 \mathrm{~cm}$ thickness. Each piece was surrounded with two pieces of butter paper before filling in polyethylene bags. Each bag was electric sealed before storing at $5{ }^{\circ} \mathrm{C}$ in refrigerator. (Amin and Keshk, 2008).

\section{Physical methods:-}

Colour of the prepared meat patties was determined using Lovibond Schofield Tintometer and expressed as blue, yellow and red colour fractions (Makinney and Little, 1962). pH of meat patties was measured using Digital 500 Eutch Cybernetics Scan $\mathrm{pH}$ meter after blending $15 \mathrm{~g}$ meat patties with $150 \mathrm{ml}$ deionized water for 2 min. (Xiong et al., (1993).

\section{Chemical methods:-}

Analytical methods:- Moisture, Protein, crude ether extract and ash contents of meat pattes were detemined according to AOAC (1998). Carbohydrate content eas calculated by difference. Thiobarbituric acid (TBA)as $\mathrm{mg}$ malondialdehyde/Kg meat patties was spectrophotomatrically determined at $532 \mathrm{~nm}$ using Specteronic 601-Milto-Ray spectrophotometer as mentioned by Siu and Draper (1978). Peroxide value was determined according to Pearson et al., (1981).

\section{Preparation of artichoke waste extracts:}

The artichoke waste extract was obtained by extraction of wastes (bracts, part of receptacles and pedicle of heads) from fresh-handling and industrial processing of artichoke hearts with methanol. The artichoke wastes $(500 \mathrm{~g})$ was crushed and then extracted three times with 21 of the solvent by stirring for $4 \mathrm{~h}$ at $40^{\circ} \mathrm{C}$. After filtration through a folder filter, the supernatants were joined and concentrated under reduced pressure using a rotary evaporator until dryness (Rabaneda et al., 2003).

Determination of total phenolic content:- The total phenolic content was determined in the extract following the Folin-Ciocalteu method (Singleton \& Rossi, 1965). The reaction mixture was composed of $0.1 \mathrm{ml}$ extract, $7.9 \mathrm{ml}$ distilled water, $0.5 \mathrm{ml}$ of FolinCiocalteu 's reagent, and $1.5 \mathrm{ml}$ of a $20 \%$ sodium carbonate anhydrous solution (added $2 \mathrm{~min}$ after the Folin - Ciocalteu 's reagent). After initial mixing the opaque flasks were allowed to stand for $2 \mathrm{hrs}$. The optical density of the blue coloured samples was determined as gallic acid equivalents (GAE) and the values are expressed as $\mathrm{mg}$ of gallic acid $/ 100 \mathrm{~g}$ artichoke wastes.

Antioxidant activity:- Antioxidant activity was measured by the N,N-Dimethyl - p- phenylenediamine dihydrochloride (DMPD). Two hundred and nine $\mathrm{mg}$ of DMPD were dissolved in $10 \mathrm{ml}$ of deionized water. One $\mathrm{ml}$ of this solution was added to $100 \mathrm{ml}$ of $0.1 \mathrm{M}$ acetate buffer $(\mathrm{pH}=5.25$ ) then $0.2 \mathrm{ml}$ of $0.05 \mathrm{M}$ ferric chloride solution was added to obtain coloured radical cation $\left(\mathrm{DMPD}^{+}\right)$as follows: 
$\mathrm{DMPD}_{\text {(uncoloured) }}+$ oxidant $\left(\mathrm{Fe}^{3-}\right)+\mathrm{H}^{+} \rightarrow \mathrm{DMPD}^{+}$(purple coloured radical cation)
$\mathrm{DMPD}_{\text {((purple coloured radical cation) }}+\mathrm{AOH}_{\text {(antioxidant material) }} \rightarrow \mathrm{DMPD}_{\text {(uncoloured) }}+\mathrm{AO}$ (antioxidant compouds)

One $\mathrm{ml}$ of this solution was directly placed in $1 \mathrm{ml}$ plastic cuvette and its absorbance was measured at 505 nm. Standard solution of the antioxidant compounds was prepared as follows: $0.1 \mathrm{~g}$ of ascorbic acid was dissolved in $100 \mathrm{ml}$ of deionized water to obtain 1 $\mathrm{mg} / \mathrm{ml}$ of ascorbic acid. Antioxidant compounds were extracted from samples as follows: One g dried sample was added to $10 \mathrm{ml}$ methanol, then centrifuged at 2000 $\mathrm{Xg}$ for $15 \mathrm{~min}$. A volume of $50 \mu \mathrm{l}$ of standared antioxidant or sample extraction was added in the spectrometric cuvette contained $1 \mathrm{ml}$ of $\mathrm{DMPD}^{+}$ solution, and after $10 \mathrm{~min}$ at $25^{\circ} \mathrm{C}$ under continuous stirring, the absorbance was measured at $505 \mathrm{~nm}$. Buffered solution was placed in the reference cuvette. A dose-response curve was derived for ascorbic acid, by plotting the absorbance at $505 \mathrm{~nm}$ as percentage of the absorbance of the uninhibited radical cation solution according to the following equation:

Inhibition of $\mathrm{A}_{505}(\%)=\left(1-\mathrm{A}_{\mathrm{F}} / \mathrm{A}_{0}\right) \times 100$

Where:

$\mathrm{A}_{0}=$ Absorbance of uninhibited radical cation.

$\mathrm{A}_{\mathrm{F}}=$ Absorbance measured at $10 \mathrm{~min}$ after the addition of antioxidant samples. (Fogliano et al., 1999).

Microbial analysis:-Ten grams of meat patties were blended with $90 \mathrm{ml}$ of sterilized peptone water for $5 \mathrm{~min}$ in a sterilized stomacher 400 (Colworth, London,UK) for $1 \mathrm{~min}$. Appropriate dilution from $10^{-1}$ to $10^{-6}$ were prepared in sterilized peptone water to select the suitable one for enumeration using microbiological pour plate technique and recommended culture media (Gerhardt et al., 1994) . Coliform were detected by lactose broth, after incubating at $30{ }^{\circ} \mathrm{C}$ for $48 \mathrm{hrs}$. while total bacteria were counted on plate count agar (PCA).

Sensory evaluation: Colour, odour, taste and texture of the meat patties were subjectively evaluated using 10 panalist of Food Science and Technology Department, Faculty of Agriculture,Alex. University, Egypt. Hedonic ranking test where 9=extremely acceptable to $1=$ extremely rejected as described by Kramer and Twigg (1970).
Statistical procedures: F-test, and analysis of variance of treatments difference was performed according to Steel and Torrie (1980). Statistical analysis was done by, ANOVA, FACTOR F-test, and L.S.D. procedures available within the SAS software package (version 9.13 2008). Histograms were produced using Harvard graphics software (HG, version, 5. 2003).

\section{RESULTS AND DISCUSSIONS}

\section{Polyphenols and antioxidant activity of artichoke wastes extract:-}

Data in Table (1) show that, artichoke wastes extract have a considerable amount of total polyphenols $421.8 \mathrm{mg} / 100 \mathrm{~g}$, and a relatively high percent of antioxidant activity $(63.00 \%)$, these result confirmed possibility of using the extract as antioxidant source. Rabaneda et al., (2003) reported that 45 phenolic compounds were identified in artichoke waste, some of which have been reported to exhibit activity as free radical scavengers and quenchers of reactive oxygen species. Fratianni et al., (2007) found that, globe artichoke is considered a healthy food due to its nutritional and phytochemical composition. It contains a high proportion of phenolics. Meanwhile Pandino et al., (2011) confirmed that the bracts of globe artichoke could have an added economic value if exploited for the extraction of phenol compounds.

\section{Proximate analysis of fresh meat patties:-}

Table (2) shows the proximate analysis of meat patties used in this study, where it had $68.94 \%$ moisture, $17.54 \%$ protein, $9.56 \%$ fat, $1.94 \%$ ash and $2.02 \%$ carbohydrate on fresh weight basis. Data of Greenfield et al., (1981) showed that commercial hamburger contained $10.7-13.6 \%$ protein, $11.2-13.3 \%$ fat, $1.8-1.9 \%$ ash. 3.4-4.1\% sugar and 16.6-18.5\% starch on wet weight basis. Keshk et al., (2008) found that the moisture, protein, ether extract, ash and carbohydrates were ranged from 68.95 to $70.99,15.32$ to $15.6,10.24$ to $11.67,2.29$ to 2.34 and 1.05 to $1.92 \%$, in beef burger, respectively

Table 1. Total Polyphenols and antioxidant activity of artichoke waste extract

\begin{tabular}{lcc}
\hline Component & $\begin{array}{c}\text { Polyphenols } \\
\text { (mg/100g dry artichoke waste sample) }\end{array}$ & Antioxidant activity \% \\
\hline Total polyphenols & $421.80 \pm 1.6$ & $63.00 \pm 2.4$ \\
\hline
\end{tabular}


Table 2. Proximate analysis of fresh meat patties before addition of artichoke waste

\begin{tabular}{|c|c|c|}
\hline component & $\%$ in & Beef burger sample (on wet weight basis) \\
\hline Moisture & & $68.94 \pm 0.21$ \\
\hline Protein & & $17.54 \pm 0.43$ \\
\hline Crude ether extract & & $9.56 \pm 0.11$ \\
\hline Ash & & $1.94 \pm 0.05$ \\
\hline Carbohydrates $^{*}$ & & $2.02 \pm 0.04$ \\
\hline
\end{tabular}

* Carbohydrates value was calculated by difference.

Storage stability of meat patties as affected by artichoke waste extract:-

Colour and pH values:-Colour values of meat patties were evaluated using Lovibond Schofield Tintometer and shown in Table (3). Generally from the results it can be noticed that the pattie samples trend to be red to yellow in colour. Also it can be concluded that, there was no significant differences in blue colour between all studied samples at zero time of storage, but blue colour significantly increased within storage period in all samples. The results also indicated that, at zero time of storage there was no significant differences between samples A, B ,C and D for yellow color, whereas there was a significant increasing in it in sample $\mathrm{E}$ and $\mathrm{F}$ whose contained artichoke wastes extract. However, there was a slightly change in yellow color for all samples within storage. Meanwhile, the red colour was the dominant color in all samples at zero time, but it significantly decreased in all samples within storage period. Also, as it shown from the results, in the beginning of storage period red color was high in samples A and B followed by samples C,D,E and more less in sample $\mathrm{F}$, but at the end of the storage period sample $\mathrm{F}$ represented the highest value of red colour among the other 9 days stored samples. Moreover, almost all the pattie samples trend to be more yellow to red colour at the end of storage period. Banon et al., (2007) confirmed the changes of colour that are normally associated with the loss of redness in meat during storage.

Table (4) illustrates $\mathrm{pH}$ values for studied meat pattie samples control one and samples after addition of artificial preservatives and artichoke extracts, the results indicated that, there were significant differences between $\mathrm{pH}$ values of all treatment at zero time and during storage period. At zero time of storage control sample (A) had a highest value of $\mathrm{pH}$ followed by sample F, E, B,C and D, in descending order. During storage time, there were a noticed significant differences in $\mathrm{pH}$ values between stored meat pattie samples, where, $\mathrm{pH}$ values of control sample were decreased from 5.76 to 4.63 during the storage period up to 9 days.
Also $\mathrm{pH}$ values of sample B decreased significantly after storage period of 6 and 9 day and the same trend was observed for sample $\mathrm{D}$, this decrease in $\mathrm{pH}$ values, perhaps, is due to growth of some strains of microorganism that produce acids in stored meat patties samples. Samples E and F which contained artichoke extract showed a slightly change in $\mathrm{PH}$ values. AlesonCarbonell et al., (2004) reported that commercial hamburger had $5.24-6.4 \mathrm{pH}$ values.

Bacterial count: It is known that refrigeration at $5^{\circ} \mathrm{C}$ does not kill microorganisms but able to retard their growth and slow the rate of both enzymatic and nonenzymatic changes. Data in Table (5) show the total count of bacteria and the detection of coliform group in studied meat pattie samples during storage period, from the results it can be noticed that, in control sample there was a noticeable increment in total count of bacteria within time and at 9 days of storage the plate was very crowded with colonies and could not be detected. After 3 days of storage the large number of colonies were found in control sample (A) flowed by B,D,E,C and F treatment in descending order. Total count of bacteria was maximized at the end of storage period (after 9 days of storage) in treatment A flowed by B,D,C,E and $\mathrm{F}$ treatment in descending order. From the above results it can be concluded that, at the end of cold storage period of meat pattie samples, sample $F$ which was containing $800 \mathrm{mg}$ artichoke extract/Kg meat patties had a lowest number of bacteria within storage followed by treatment $\mathrm{E}$ which had $400 \mathrm{mg}$ artichoke extract $/ \mathrm{Kg}$ meat patties, treatment $\mathrm{C}$ with $100 \mathrm{mg} \mathrm{So} 2+400 \mathrm{mg}$ sodium ascorbate, treatment $\mathrm{D}$ with $100 \mathrm{mg} \mathrm{So} \mathrm{So}_{2}+200$ $\mathrm{mg}$ artichoke wastes extract and finally treatment B with $100 \mathrm{mg} \mathrm{So}_{2}$ in ascending order . Coliform group were not detected in all treatments at zero time of storage, meanwhile they were detected in treatment A after 3 days of storage and treatment $\mathrm{A}$ and $\mathrm{B}$ after 6 and 9 days of storage. Jay (1986) reported that most food have total viable count less than $10^{6} / \mathrm{g}$ have an acceptable quality, which those having $10^{7}$ to $10^{8} \mathrm{cfu} / \mathrm{g}$ are generally have detectible off flavour. Mossi and Echeverrigaray (1999) confirmed the antimicrobial effect of artichoke extract against Gram positive 


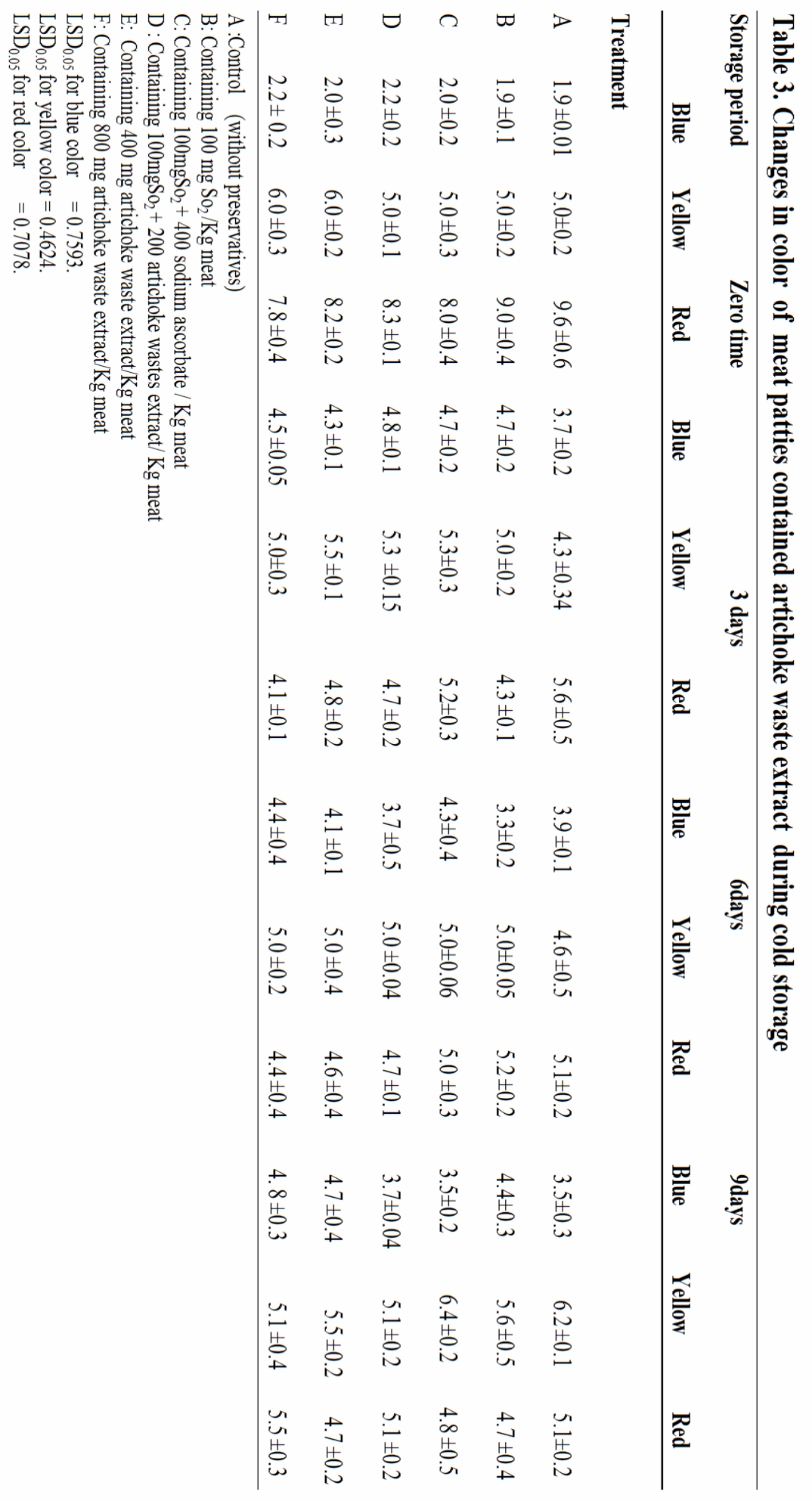


Table 4. Changes in $\mathrm{pH}$ value of meat patties within cold storage

\begin{tabular}{|c|c|c|c|c|}
\hline $\begin{array}{l}\text { Storage period } \\
\text { pH value }\end{array}$ & Zero time & 3 days & 6days & 9days \\
\hline A & $5.76^{\mathrm{a}} \pm 0.05$ & $4.26^{\mathrm{j}} \pm 0.05$ & $4.46^{\mathrm{ij}} \pm 0.4$ & $4.63^{\text {ghij }} \pm 0.28$ \\
\hline B & $5.23^{\text {cde }} \pm 0.3$ & $5.30^{\text {bcde }} \pm 0.1$ & $4.50^{\text {hij }} \pm 0.38$ & $4.73^{\text {fghi }} \pm 0.15$ \\
\hline $\mathrm{C}$ & $5.16^{\mathrm{def}} \pm 0.15$ & $5.10^{\mathrm{def}} \pm 0.1$ & $4.86^{\text {efghi }} \pm 0.9$ & $5.10^{\mathrm{def}} \pm 0.17$ \\
\hline $\mathrm{D}$ & $5.06^{\mathrm{defg}} \pm 0.2$ & $5.76^{\mathrm{a}} \pm 0.05$ & $5.43^{\text {abcd }} \pm 0.43$ & $4.93^{\text {efgh }} \pm 0.15$ \\
\hline $\mathrm{E}$ & $5.43^{\mathrm{abcd}} \pm 0.16$ & $5.46^{\mathrm{abcd}} \pm 0.15$ & $5.70^{\mathrm{ab}} \pm 0.19$ & $5.16^{\mathrm{def}} \pm 0.05$ \\
\hline $\mathrm{F}$ & $5.66^{\mathrm{abc}} \pm 0.05$ & $5.26^{\text {bcde }} \pm 0.05$ & $5.28^{\text {bcde }} \pm 0.24$ & $5.23^{\mathrm{cde}} \pm 0.05$ \\
\hline
\end{tabular}

A: Control (without preservatives)

B: Containing $100 \mathrm{mg} \mathrm{So}_{2} / \mathrm{Kg}$ meat

C: Containing $100 \mathrm{mgSo}_{2}+400$ sodium ascorbate / $\mathrm{Kg}$ meat

D: Containing $100 \mathrm{mgSo}_{2}+200$ artichoke wastes extract / Kg meat

E: Containing $400 \mathrm{mg}$ artichoke wastes extract $/ \mathrm{Kg}$ meat

F: Containing $800 \mathrm{mg}$ artichoke wastes extract $/ \mathrm{Kg}$ meat

Means in column or row not sharing the same manuscript are significantly different at $\mathrm{P} \leq 0.05$

bacteria. Capita et al., (2004) stated that the enumeration of total aerobic count and Enterobacteriacease gives information about the hygienic performances of meat production. Banon et al., (2007) reported that, addition of $100 \mathrm{mg} \mathrm{So} / \mathrm{kg}$ was not sufficient to delay the growth of total aerobic bacteria and total coliforms in raw beef patties. Results in Table (5) indicated that addition of artichoke wastes extract to the meat patties decreased the total count of bacteria during storage period compared to control samples (without preservatives) and those with $\mathrm{So}_{2}$ and sodium ascorbate. Meanwhile samples with artichoke wastes extracts had no coliform group till the end of cold storage period ( 9 days). These results confirmed possibility of using artichoke wastes extract as antimicrobial agent.

Peroxide value and thiobarbituric acid:- Figure(1) shows peroxide values of stored meat patties. From the Figure, it can be noticed that there was significant increase in peroxide values of all samples specially the control one compared with other treatments. At the end of cold storage period ( 9 days), peroxide values reached to $6.15,4.49,4.29,3.58,3.35$ and 2.37 m.eq. $\mathrm{O}_{2} / \mathrm{Kg}$ in samples A,D,B,E,C and F respectively. Figure (2) shows the changes in thiobarbituric acid (TBA) of studied meat patties at zero time and within storage period ( 3,6 and 9 days). From the Figure it can be summarized that, there was a gradual increase in TBA values during cold storage of meat patties, all samples had low value of TBA at zero time, meanwhile, increasing TBA values was more pronounced in control sample compared with others during storage period. At the end of storage, the TBA values reached 1.6, 0.84, $0.62,0.48,0.43$ and $0.28 \mathrm{mg}$ malondialdehyde $/ \mathrm{Kg}$ in samples A,B,C,D.E and F, respectively.
From the results of peroxide and thiobarbituric acid values it can be concluded that addition of artichoke extract to meat patties could retard oxidation process and keep each or TBA and PV value low compared with the control one (without preservatives) or those which contained artificial preservatives. Mossi and Echeverrigaray (1999) reported that in various pharmacological test systems, artichoke leaf extracts have shown antibacterial, antioxidative, bile-expelling, hepatoprotective, urinative, and choleretic activities as well as the ability to inhibit cholesterol biosynthesis and LDL oxidation. McCarthy et al., (2001) and Tang et al., (2001) reported that the natural equivalent of synthetic antioxidants is important with regard to human health because some synthetic antioxidants have carcinogenic activity and their usage in food industry more than natural antioxidants. The results of Banon et al., (2007) pointed to the possibility of using low $\mathrm{SO}_{2}$-vegetable extract combination to preserve raw meat products.

Organoleptic properties:- As seen from the results in Table (6) panelists accepted the determined organoleptic properties of meat patties free or containing preserving agent or artichoke extracts, all treatments were accepted within storage period except $\mathrm{A}$ and $\mathrm{B}$ treatments. Treatment $\mathrm{A}$ was unacceptable in all properties after 6 days of storage, meanwhile, treatment B was unacceptable for odour, taste and texture at the end of storage period. Samples for other treatments were acceptable in all organolyptic properties until the end of cold storage period (9 days). Banon et al., (2007) reported that in general, minor losses of colour, odour, flavour and texture were observed during storage of meat patties. 


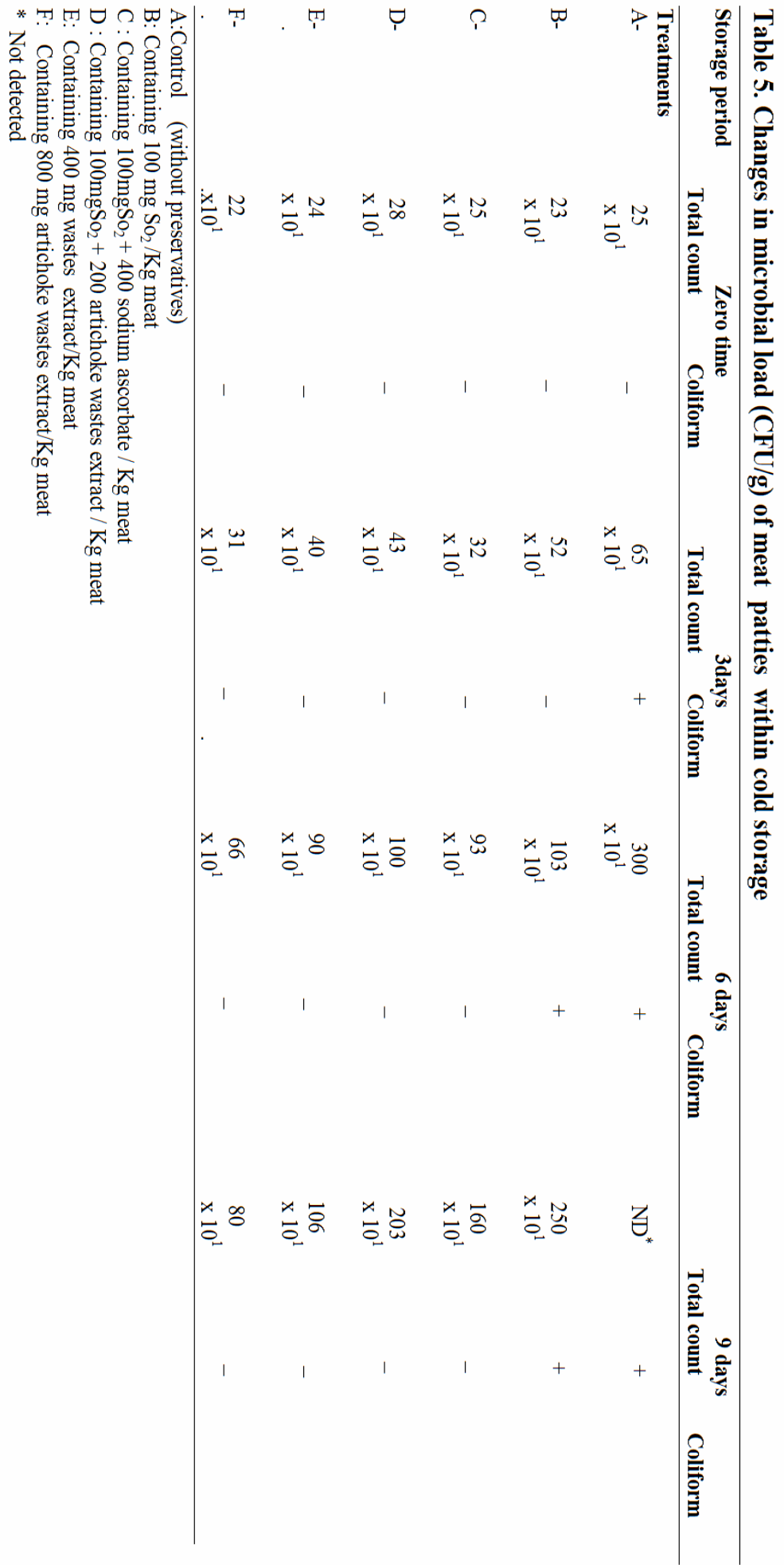




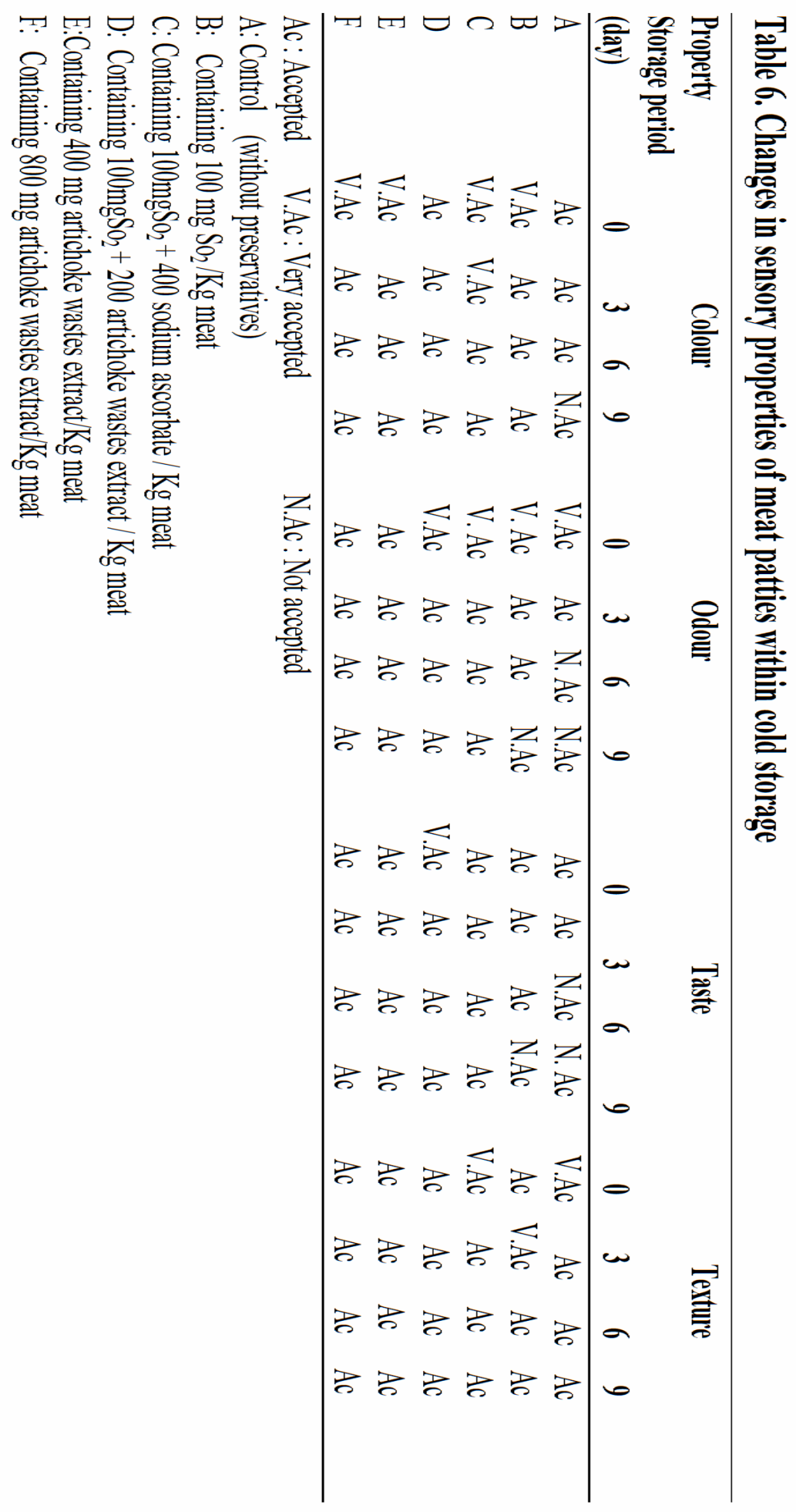




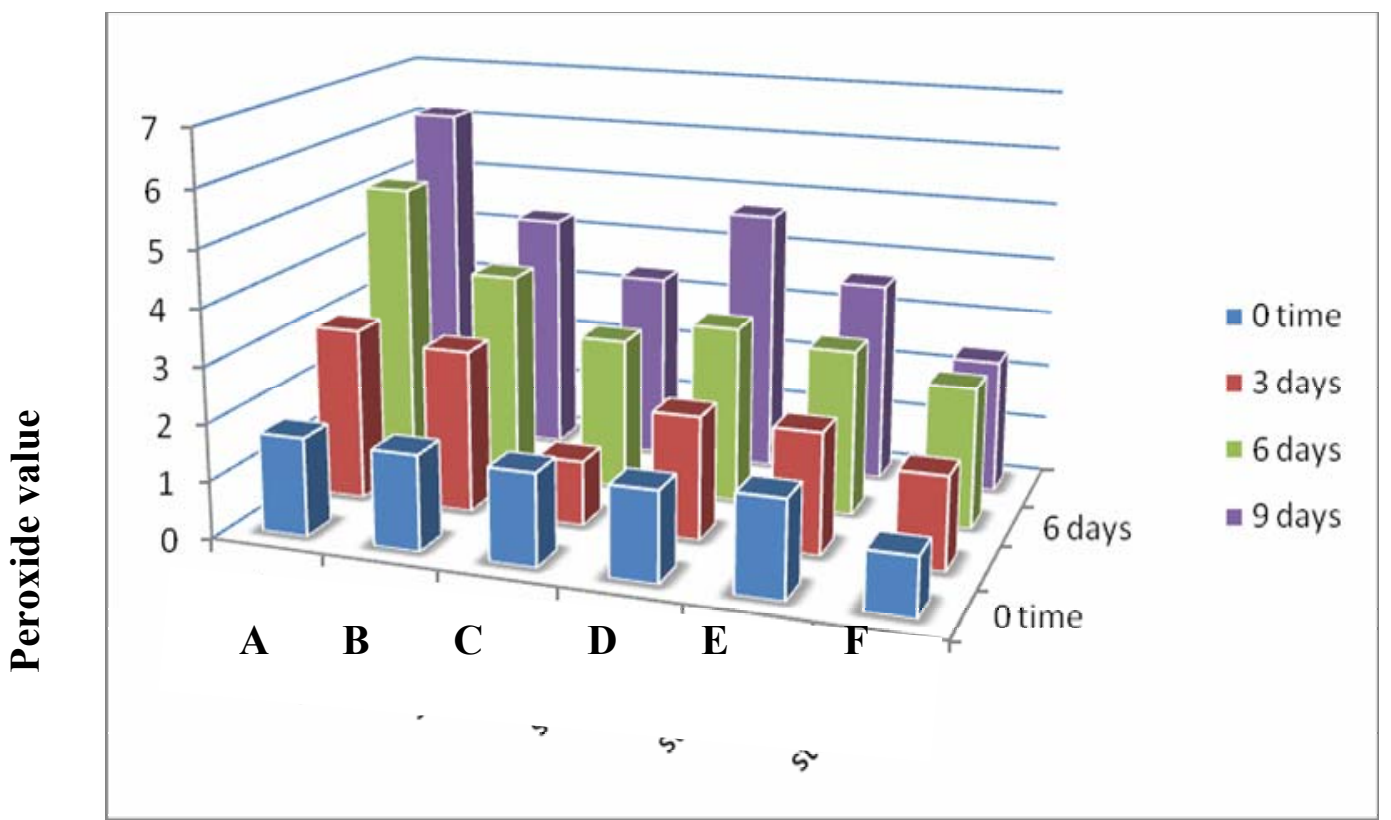

Fig .1. Changes in peroxide value of cold stored meat patties

A: Control (without preservatives)

B: Containing $100 \mathrm{mg} \mathrm{So}_{2} / \mathrm{Kg}$ meat

C: Containing $100 \mathrm{mgSo}_{2}+400$ sodium ascorbate / $\mathrm{Kg}$ meat

D: Containing $100 \mathrm{mgSo}_{2}+200$ artichoke wastes extract / Kg meat

E: Containing $400 \mathrm{mg}$ artichoke wastes extract $/ \mathrm{Kg}$ meat

F: Containing $800 \mathrm{mg}$ artichoke wastes extract/Kg meat

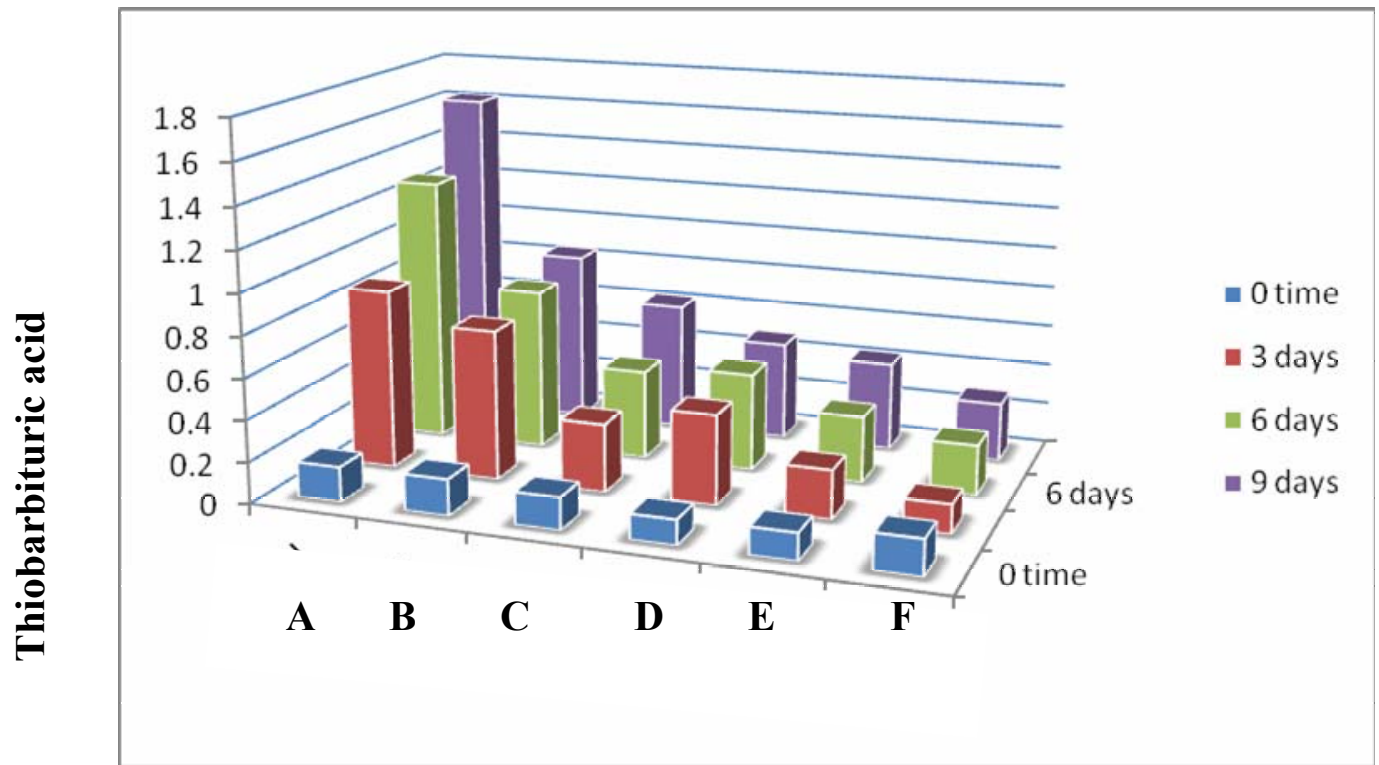

Fig.2. Changes in thiobarbituric acid (TBA) of cold stored meat patties

A: Control (without preservatives)

B: Containing $100 \mathrm{mg} \mathrm{So} / 2 / \mathrm{Kg}$ meat

C: ontaining $100 \mathrm{mgSo}_{2}+400$ sodium ascorbate / Kg meat

D: Containing $100 \mathrm{mgSo}_{2}+200$ artichoke wastes extract / Kg meat

E: Containing $400 \mathrm{mg}$ artichoke wastes extract $/ \mathrm{Kg}$ meat

F: Containing $800 \mathrm{mg}$ artichoke wastes extract $/ \mathrm{Kg}$ meat 


\section{REFERENCES}

Aleson-Carbonell, L.; Fernandez-Lopez, J.,; Sendra, E.; Sayas-Barbera,E. and Perez-Alvaez, J.A. (2004) .Quality characteristics offermented dry-cured sausage formulated with lemon albedo. J.Sci Food Agric., 48:2077-2084.

Amin,W. A. and Keshk, S. A.(2008). Preparation and evaluation of some citrus wastes to use in preparing functional foods. Alex. Sci Exchange .J.,29: 186-194.

A. O. A. C. (1998). Association of Official Analytical Chemists. Official methods of analysis of the Association of Official Analytical Chemists, Washington, 4, DU, UAS.

Banon, S.; Diaz, P.; Rodriguez, M.; Garrido, M.D. and Price,A. (2007). Ascorbate, green tea and grape seed extracts increase the shelf life of low sulphite beef patties. Meat Sci., 77: 626-633.

Bianco, V.V. (2005). Present situation and future potential of artichoke in the Mediterranean basin. Acta Horticul., 681: 39-55.

Capita,R.; Prieto, M. and Alonso-Calleja, C. (2004). Sampling methods for microbiological analysis of red meat and poultry carcasses: A Review Meat Sci., 64:1303-1308.

Dranik, L.I.; Dolganenko, L.G.; Slapke,J.; and Thomas,N. (1996). Chemical composition and medical usage of Cynara scolymus L. Rastit Resur., 32: 98-104.

Fogliano, V.; Verde, V.; Randazzo, G. and Ritieni, A. (1999) . Method for measuring antioxidant activity and its application to monitoring the antioxidant capacity of wines.J. Agric.Food Chem.,47:1035-1040.

Fratianni,F.; Tucci,M. ; De palma, M.; Pepe,R. and Nazzaro, F. (2007). Polyphenolic composition in different parts of some cultivars of globe artichoke (Cynara cardunculus L. var. scolymus(L.) Fiori) Food Chem.,104:1282-1286.

Gerhardt,P.; Marray, R.G.E; Castitlow, R.N.; Nester, E.W.; Wood, W.A and Philips, G.B. (1994). Manual of methods for general bacteriology. Washington; American Society for Microbiology.

Greenfield, H.; Chuah, L.K. and Wills, R.B. (1981). Composition of Australian foods, 12.Hamburger. Fd. Technol. In Australia., 33: 619-623.

Jay,T.M. (1986) . Food Born Microorganisms and Their Toxins, Developing Mythology Marcel Dekker. New York.

Kramer, A. and Twigg, B.A. (1970). Quality control for the food industry $3^{\text {th }}$. AVI Publishing Co. Westport Conn. London. England.

Keshk,S. A.; El Razek, A.A.; and Amin, W.A. (2008). General

characteristics and storage stability of beef burger containing citrus wastes mixture Alex. Sci. Exchange. J. 4.,208-216.
Loliger, J. (1991). The use of antioxidants in food. In Free Radicals and Food Additives; Aruoma, O. I., Halliwell, B., Eds.; Taylor and Francis; London,pp ; 129-150.

Makinney,G. and Little, A. (1962). Colour of Food. The AVI.PublishingCompany.INC.

McCarthy,T.L; Kerry,J.P.; Kerry, J.F.; Lynch, P.B. and Buckley,D,J.(2001). Evaluation of the antioxidant potential of natural food/plant extracts compared with synthetic antioxidants and vitaminE in raw and cooked pork pattied. Meat Sci., 57: 545-552.

Mossi,A.J.and Echeverrigaray, S. (1999).Identification and characterization of antimicrobial components in leaf extract of globe artichoke (Cynara scolymus L.). Acta Hrtic., 501:111-114.

Mulinacci, N.; Prucher, D.; Peruzzi, M.; Romani, A.; Pinelli, P.; Giaccherini.C. and Vincieri, F.F.(2004). Commercial and laboratory extracts from artichoke leaves: estimation of caffeoyl esters and flavonoidic compounds content. J. Pharm. Biom.l Anal.., 34: 349-357.

Pandino, G.; Lombardo, S.; Mauromicale, G.; and Williamson, G. (2011). profile of polyphenols and phenolic acids in bracts and receptacles of artichoke ( Cynara cardunculus var. scolymus ) germplasm. J. Food Composition and Analysis. , 24:148-153.

Pearson, D.; Egan, H.; Kirk,R.S. and Sawyer, R. (1981). Chemical analysis of food. Longman Scientific and Technical, New York.

Rabaneda,F.S.; Jauregui,O.; Raventos,R.M.L.; Bastida,J.; Francesc, V. and Calles C. (2003). Identification of phenolic compounds in artichoke waste by high performance liquid chromatography- tendem mass spectrometry. J. Chrom., A 1008: 57-72.

Singleton,V.L., \& Rossi, J.A. (1965). Colorimetry of total phenolics with Phosphomolybdic-phosphotungstic acid reagents. Amer. J. of Enol. and Viticult., 16: 144-158.

Siu, G.M. and Draper, H.H.A. (1978) . Asurvey of the malonaldehyde content of retail meats and fish. J. Food . Sci.,43:1147-1149.

Steel, R.G. and Torrie, J. H (1980). Principles and procedures of statistics 2 nd ed. McGraw Hill, New York, U.S.A.

Tang,S., Kerry, P.P., Sheehan,D., Bukley, D.J. and Morrissey,P.A. (2001) Antioxiddative effect of added tea catechins on susceptibility of cooked red meat, poultry and fish patties to lipid oxidation. Food Res. Internat. .,34: 651-657.

Xiong,Y.L., Cantor, A.H., Pescatore, A.J., Blanchard, S.P.\& Straw, M.L (1993). Variations in muscle chemical compositions, $\mathrm{pH}$ protein extractability among eight different broiler crosses . Poultry Sci., 72: 583-588. 


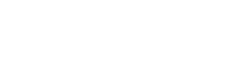

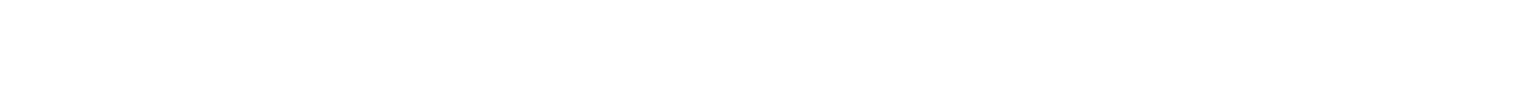

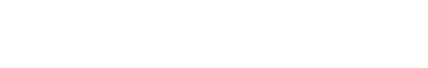

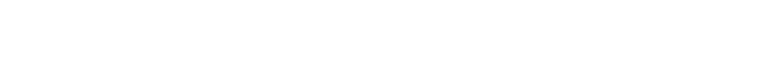

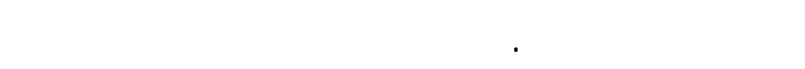

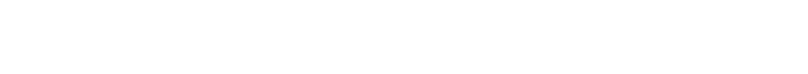

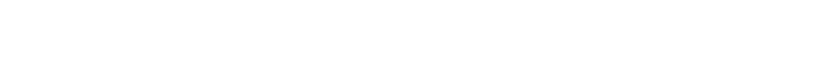

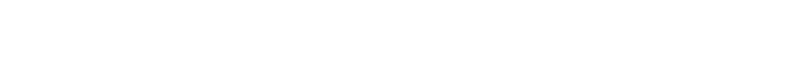

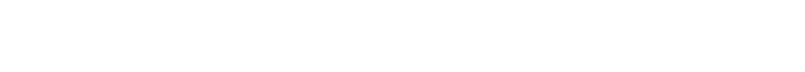

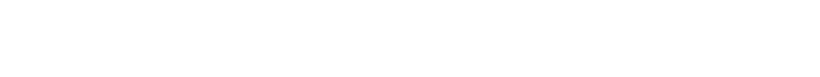

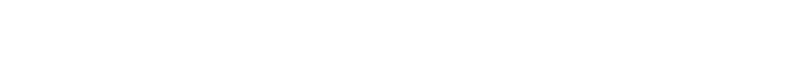

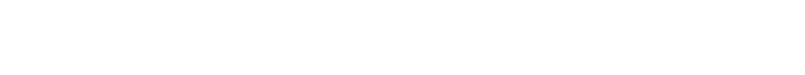

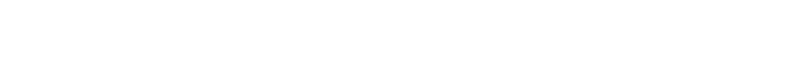

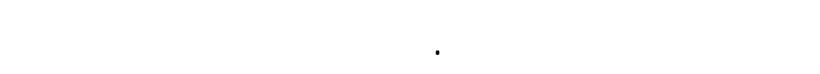

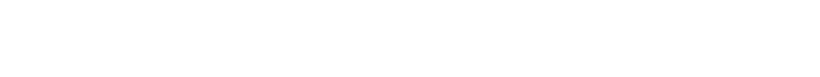

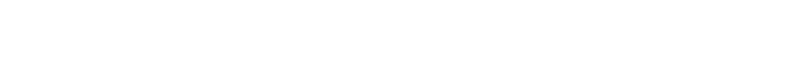

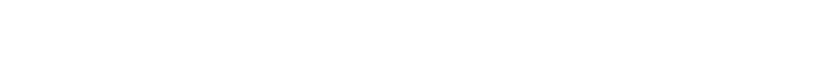

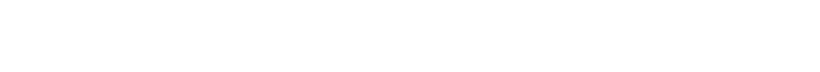
مرفوضة من قلى المكم].

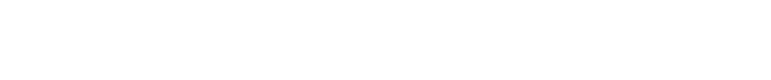

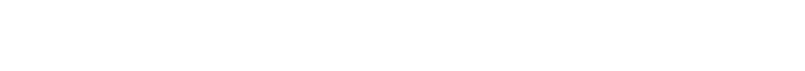

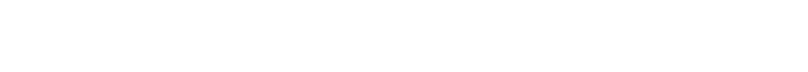

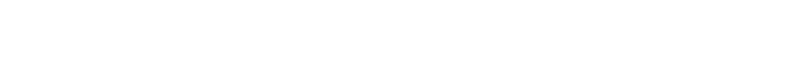

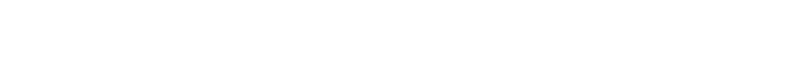
وإلبكروبت للمستخل موضع الدرلسة، حيث لظٔلهرت النت ائج

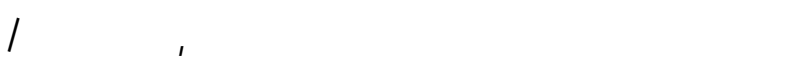

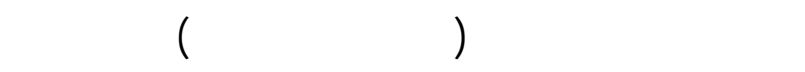

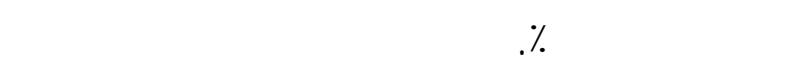

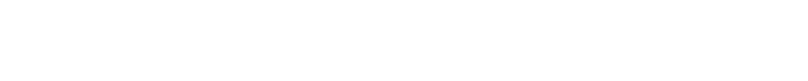

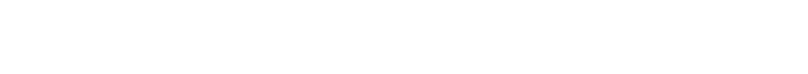

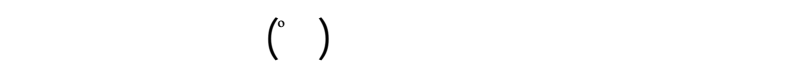

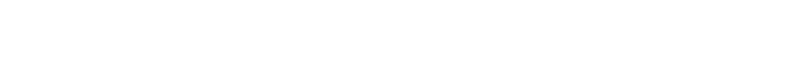

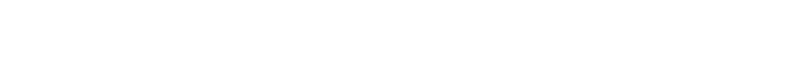
التأكسى للعينت على مدى فترات التخزين(صفر، ب، و، 7 أيلم) 